\title{
10
}

\section{The world's most liveable city-for Māori: data advocacy and Māori wellbeing in Tāmaki Makaurau (Auckland)}

\author{
James Hudson
}

What would the world's most liveable city look like? This is a question that is being considered by iwi (Māori tribes) and Māori communities within Tāmaki Makaurau (Auckland) in Aotearoa (New Zealand). This is a question that is also being considered by the Auckland Council, the local government authority for the Tāmaki Makaurau region. However, while Māori and the Auckland Council may be asking the same question, the responses are not necessarily, if at all, similar. This can be attributed (at the risk of oversimplifying) to dissimilar, and at times competing, values and world views underpinning the array of responses from Māori of Tāmaki Makaurau and Auckland Council.

Tāmaki Makaurau, as with the rest of Aotearoa, experienced colonisation by British settlers during the early 1800s, resulting in drastic loss of land, crippling depopulation and cultural erosion for Māori (Walker 2004). Today, however, due to a range of Māoriinitiated developments, the Māori population has grown and arrived at a point where it is now larger and living longer than at any point in history (Durie 2005). And, during the past three decades, catalyst 
events such as the Hui Taumata (Māori Economic Summit) in 1984 have provided the contemporary thrust by which Māori have acted strategically at national and local government levels to establish laws and policies that empower their iwi and communities and which utilise more traditional Māori concepts and structures (Māori Economic Development Taskforce 2010). This is notwithstanding the custodial approaches of successive governments to apply assimilative policies to Māori development, which drove broader government agendas and quickly dismissed notions of Māori self-determination (Durie 2009).

This chapter explores the Māori and Auckland Council relationship within the context of negotiating a shared vision for Tāmaki Makaurau. The focal point is 'The Māori Plan for Tāmaki Makaurau', a plan constructed, with Māori of Tāmaki Makaurau, by the Independent Māori Statutory Board (IMSB), a statutory advisory board to the Auckland Council. The Māori Plan clearly articulates a Māori vision for Tāmaki Makaurau and is a touchstone for ongoing dialogue about Māori-specific data to support that vision. The chapter discusses the work of the IMSB in utilising and advocating for Māori-specific data to promote and advocate positive outcomes for Māori in Tāmaki Makaurau. And it shares some experiences and reflections to promote constructive discussion and reflective analysis that may be relevant for other local government contexts within Aotearoa or for wider international and indigenous contexts.

\section{Background}

\section{Māori in Tāmaki Makaurau}

The Māori population of Tāmaki Makaurau is approximately 142,767 people-one-quarter of the entire Māori population of Aotearoa (Statistics New Zealand 2013). It is overwhelmingly young, with over half the population aged 24 years or younger and less than 4 per cent aged 65 years or older (Statistics New Zealand 2013). And while there are more male Māori in age groups up to 19 years, females predominate in all remaining age groups (Statistics New Zealand 2013). 
Mana whenua are 'the people of the land', the iwi, and have an enduring relationship with Tāmaki Makaurau. Tāmaki Makaurau is their türangawaewae - their place in the world. Mataawaka represent the wider Māori population and include Māori residents and ratepayers who are service users and stakeholders.

\section{The Treaty of Waitangi and local government}

Auckland Council's obligation to provide for Māori is ultimately grounded in and guided by the Crown's obligations under Aotearoa's founding constitutional document, the Treaty of Waitangi of 1840. In part due to the differences in interpretation in the English and Māori versions of the treaty, most contemporary legislation refers to the principles of the treaty, rather than the specific treaty provisions themselves (Belgrave 2012). The dominant principles articulated by the judiciary (though understood to be evolving) are: partnership (which includes the duty on both parties to act reasonably, honourably and in good faith), active protection (which requires the government to protect Māori interests) and redress (which requires the government to take active and positive steps to redress breaches of the treaty) (Wheen \& Hayward 2012).

The duty to consult with Māori has been described as a principle inherent in the treaty and in the overarching principles of partnership and active protection. ${ }^{1}$ At a local government level, the duty to consult with Māori is also required under two primary pieces of legislation. The first, the Local Government Act 2002, requires councils to establish and maintain processes to provide opportunities for Māori to contribute to the decision-making processes of the local authority. The second, the Resource Management Act 1991, requires that councils consult with Māori authorities at various stages under the Act, including during the development of resource management plans.

It is within this context of a treaty partnership, and the various legislative and policy requirements to adequately consult, that current discussions are occurring among Māori and the Auckland Council concerning a vision for Tāmaki Makaurau.

$1 \quad$ New Zealand Māori Council v Attorney-General [1897] 1 NZLR 683. 
In 2009, the national government implemented bold changes to the governance system of Tāmaki Makaurau whereby the seven city and district councils existing at that time, along with the Auckland Regional Council, were disestablished and amalgamated into a new, unitary council, the Auckland Council. ${ }^{2}$

The amalgamation of these governing bodies, however, did not diminish Auckland Council's legal obligations and responsibilities towards Māori. And debate soon ensued concerning the best way in which treaty and legal obligations towards Māori in Tāmaki Makaurau could be met. A significant outcome of this debate was the establishment of the IMSB.

\section{The Independent Māori Statutory Board}

In its report to the government, the Royal Commission on Auckland Governance (2009) recognised that Māori constitute a unique community of interest with special status as a partner under the Treaty of Waitangi and recommended that Mãori be guaranteed seats on the Auckland Council. However, the government chose not to adopt the Royal Commission's recommendation, opting instead to establish a Māori Advisory Board with a nonbinding consultative role before the Auckland Council. It was at this point that the IMSB was established under the Local Government (Auckland Council) Act 2009.

The IMSB's broad purpose is twofold: to assist the Auckland Council to make decisions, perform functions and exercise powers by promoting cultural, economic, environmental and social issues of significance for Māori in Tāmaki Makaurau; and to ensure that the Auckland Council acts in accordance with statutory provisions referring to the treaty. To achieve this purpose, the IMSB's primary functions include advising the Auckland Council on matters affecting Māori and working with the Auckland Council on the design and execution of documents and processes to implement the council's statutory responsibilities towards Māori.

2 Local Government (Tamaki Makaurau Reorganisation) Act 2009, Local Government (Auckland Council) Act 2009 and Local Government (Auckland Transitional Provisions) Act 2010. 
The IMSB is made up of nine representatives of Mana Whenua and Mataawaka, who are appointed by a process designed by Māori. They meet at least quarterly with the Auckland Council Governing Body. The IMSB members also sit on various targeted Auckland Council committees to advocate on behalf of Tāmaki Makaurau Māori. The IMSB is supported by a secretariat that includes policy advisors, technical staff and data analysts, each of whom engages with Auckland Council at an officer level. At these two levels of engagement-governance and operational - the IMSB is able to influence and advocate on behalf of Tāmaki Makaurau Māori.

\section{The Māori Plan}

Early in its inception, the IMSB identified that existing regional development frameworks and measures had failed to adequately provide for Māori identity and wellbeing. It also recognised the dearth of Māori-specific data at a regional level that were useful or relevant for informing their own and Auckland Council's regional strategies, policies and planning for Māori in Tāmaki Makaurau. While some data were available about Māori, few, if any, were available that could be viewed as data useful for Māori.

Therefore, in mid 2011, the IMSB initiated a process to explore an approach to monitor and measure Māori outcomes in Tāmaki Makaurau. The IMSB sought views from Mana Whenua and Mataawaka within Tāmaki Makaurau and reviewed relevant policy and planning documents from both Māori and Auckland Council. The process confirmed that, at that time, there was no existing framework that enabled the IMSB to measure Māori wellbeing in Tāmaki Makaurau in accordance with Māori world views and Māori values. Work therefore began on constructing such a framework.

An initial step was completing a critical review of the major approaches that are relevant to conceptualising and measuring Māori wellbeing. High-level approaches to wellbeing were analysed and the main strengths and shortcomings of each were identified. The review concluded that there were several kinds of approaches to measuring Māori wellbeing, all of which had the potential to provide a different snapshot of Māori wellbeing (Cunningham 1996; Durie et al. 2002; Kingi 2005; Baker 2010). Several of the approaches had a degree 
of overlap with respect to the concepts, indicators and data used, but varied in terms of how the information was framed and the underlying objectives or goals.

A mixed-method approach to constructing the Māori Plan was therefore proposed, which aligned with the priorities and interests of the Auckland Council, its business units and central government agencies, but still reflected the needs and aspirations of Māori in Tāmaki Makaurau. The review also found that the Māori Plan would need a robust translational process that ensured a good fit between the project's goals, the definition of wellbeing, the measurement dimensions and the available data sources.

Following this review, Mana Whenua and Mataawaka were engaged again to elicit an independent Māori voice to articulate their vision for their collective wellbeing in Tāmaki Makaurau. Significant engagement included 23 hui (gatherings) with Mana Whenua and Mataawaka and 10 hui with rangatahi Māori (Māori youth). The engagement exercise revealed a wide range of opinions about Māori wellbeing in Tāmaki Makaurau and contributors to improving it. Significantly, the engagement found that:

1. Mana Whenua and Mataawaka aspirations were holistic and crossed several domains

2. Māori values were integral to Mana Whenua and Mataawaka aspirations for the future

3. economic aspirations for Tāmaki Makaurau required further investigation and development

4. there were opportunities to connect and participate globally

5. greater value needed to be placed on Māori culture

6. there should be greater opportunities for Māori communities to connect with each other, and externally, to provide social cohesion.

Further, the engagement with Mana Whenua and Mataawaka also identified that the Māori Plan belonged to Māori; the role of the IMSB was as a kaitiaki (guardian) of, and advocate for, the Māori Plan rather than its owner. 
The data and research gathered through the literature review and engagement processes were then analysed using Māori-centred approaches. An important output of this process was the Māori Plan, the indicators matrix of which is shown in Figure 10.1.

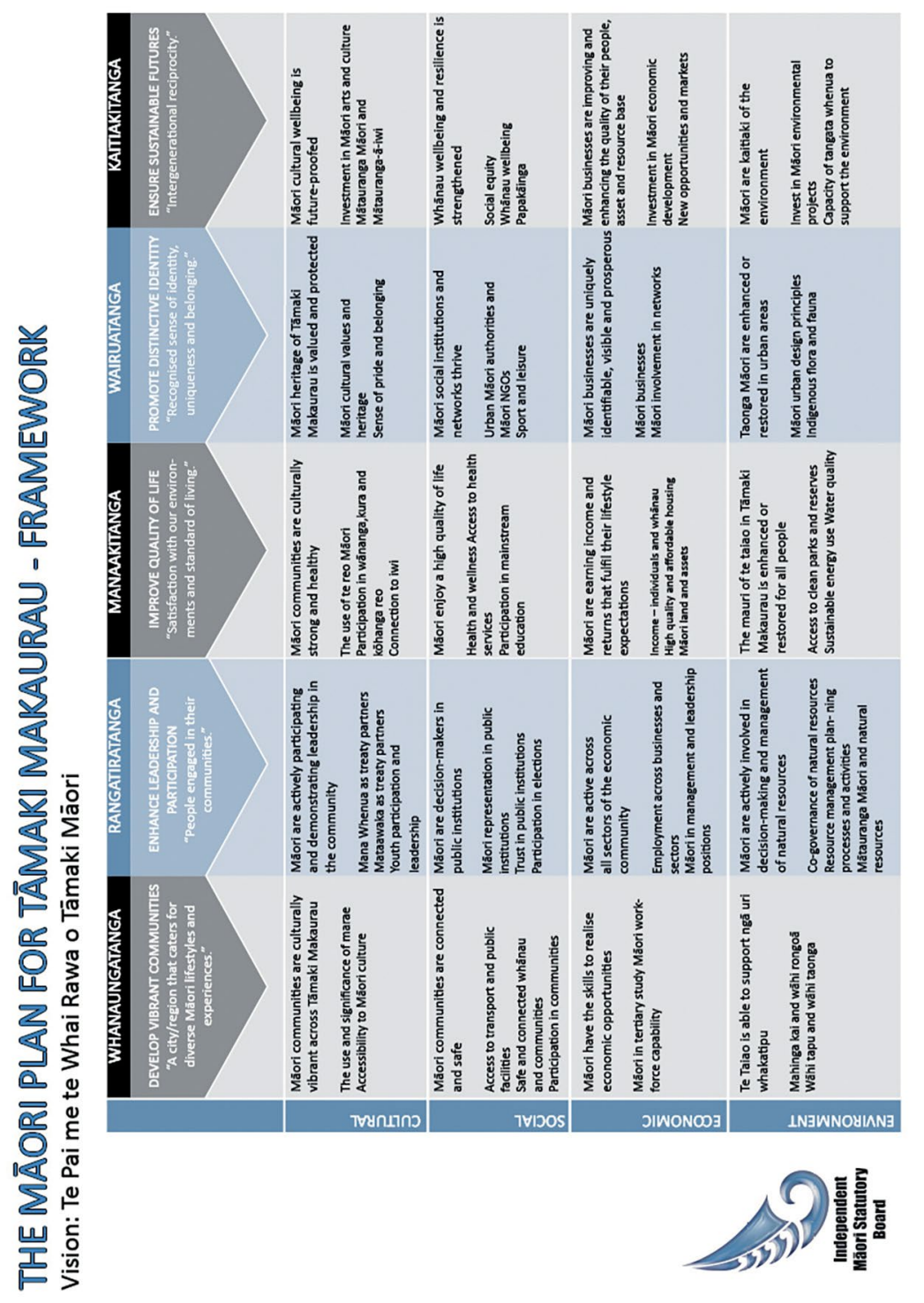

Figure 10.1 The Māori Plan for Tāmaki Makaurau

Source: IMSB (no date). 
The Māori Plan is an aspirational 30-year plan for Māori in Tāmaki Makaurau. It provides the IMSB with a basis for prioritising issues, advocating for opportunities and forming partnerships with Auckland Council and other partners to deliver improved wellbeing for Māori communities. It is intended to be a touchpoint whereby the IMSB is able to provide direction to Auckland Council in developing policies, practices and plans relevant to Tāmaki Makaurau Māori. The Māori Plan was developed so it could be revised and refreshed over time to remain relevant to Mana Whenua and Mataawaka while providing the IMSB and Auckland Council with a basis from which to focus on key activities relating to Māori development within Tāmaki Makaurau.

The Māori Plan is underpinned by Māori values, emphasising the idea that Māori can contribute their own world views and practices to policies and plans in a way that is meaningful and constructive to them. The values are whanaungatanga (relationships), rangatiratanga (autonomy and leadership), manaakitanga (to protect and look after), wairuatanga (spirituality and identity) and kaitiakitanga (guardianship).

The Māori Plan includes key directions, which emerged from the analysis of the engagement meetings and key documents, and which reflect the overarching goals or aspirations that Māori have for their own tribes, organisations and communities. The key directions (which are located vertically in the plan) are: 1) developing vibrant communities; 2) enhancing leadership and participation; 3) improving quality of life; 4) promoting a distinctive Māori identity; and 5) ensuring sustainable futures.

The Māori Plan has four domains, or wellbeing areas: social, cultural, economic and environmental. And within each domain are focus areas, specific issues that Māori highlighted as being important to them-for example, accessibility to Māori culture, Māori in tertiary study, sustainable energy use and investment in Māori economic development.

Finally, and of particular relevance to this chapter, is the Māori Plan's set of state of wellness indicators - state indicators that provide the basis for the long-term measurement and monitoring of Māori wellbeing in Tāmaki Makaurau. They are relatively high level to identify trends and provide an evidential basis for the formulation of policies and 
actions. The indicators also act as accountability mechanisms to ensure that the Auckland Council and other agencies are responsive to Māori issues. The process of selecting indicators to populate the Māori Plan's framework was undertaken iteratively with the development of the focus areas and evaluated collaboratively with Māori and other stakeholders. The indicators rely on a range of data sources, including the New Zealand Census of Population and Dwellings, the Auckland Quality of Life Survey and central government and Auckland Council administrative data.

\section{The Māori Plan: challenges and implications}

There are a number of specific challenges to implementing and monitoring the Māori Plan, the first of which relates to considerations of tikanga Māori (Māori customs). Basically, the Māori Plan represents the aspirations and vision of Māori and the key directions and actions contained therein are guided by tikanga Māori. Proposed research and evaluation activities therefore need to be designed and carried out in a manner that is consistent with traditional Māori values, concepts and practices. These values imply the adoption of Māoricentred research practices where possible, the involvement of Māori in oversight of the implementation of the plan and the development of Māori research capability.

A second issue is the Māori Plan's long time horizon: 30 years. It is expected the Māori Plan will be refreshed and revised over this interval, which means the evaluation and monitoring of the plan will need to be flexible and able to accommodate change to ensure the plan remains relevant as priorities change. It also means that the reporting will need to blend short-term activities that enable early progress to be assessed with measurement of enduring indicators to enable longterm changes in wellbeing to be monitored.

Then, there is the broad range of issues of significance to Māori to consider. The Māori Plan spans a wide range of issues of significance and a diverse set of priorities. This mirrors, to a large extent, the broad range of factors that affect Māori wellbeing. It also reflects the wide span of influence of Auckland Council strategies, plans and activities. This presents challenges in terms of identifying monitoring and evaluation priorities, as it is simply not possible within available resources to 
monitor and evaluate every aspect of the Māori Plan's implementation. The IMSB is therefore required to engage in prioritisation exercises to best focus resources to progress towards positive Māori outcomes.

The review of data sources during the construction of the Māori Plan highlighted that considerable data gaps existed for Māori at the regional level, particularly in the environmental and cultural domains. In some cases, this was because ethnicity data were not collected or data were available only at the national level. The lack of existing indicators that reflect a Māori values-based approach to wellbeing was striking - both then and now - and highlights a tension that has long existed between the interests and statistical reporting requirements of government and Māori perceptions of what constitute useful and meaningful data. However, while there are a number of indicators for which no current data exist, this presents an opportunity to propose new primary research through new initiatives or ongoing collaboration between Māori, the Auckland Council and external partners.

Finally, evaluation and monitoring frameworks are typically developed for strategies, policies and programs for which there are dedicated resources and a clear intervention logic. In contrast, the Māori Plan is an aspirational document that sets out an intended vision and direction for Māori wellbeing and that has no dedicated resources committed to its implementation. The appropriate methodology for monitoring and evaluating implementation of the Māori Plan needs to reflect its aspirational status and the dependency on other parties' actions to give effect to it.

\section{The IMSB data strategy}

To some extent, the challenges above are mitigated by, first, the knowledge and experience of the IMSB members, who collectively are experts in tikanga Māori, Māori development and Māori cultural indicators. However, with respect to its work concerning Māorispecific data and research, these challenges are also being mitigated by the IMSB's recently launched 'Data strategy 2016-2020', which includes the establishment of a Data Strategy Expert Panel. 
The data strategy is premised on the same five core Māori values and, in this way, is directly linked to the Māori Plan. The data strategy was designed to enable the IMSB to advocate for data that are Tāmaki Makaurau-focused, cost-effective, accessible in a timely manner, high quality and sustainable in the sense that they are collected regularly and systematically.

The strategy also identifies key partners with whom the IMSB has developed strategic relationships to both access and advocate for the future collection of Māori-specific data. Significant relationships include those with organisations such as Statistics New Zealand, Auckland Council's Research, Investigation and Monitoring Unit and Nga Pae o te Maramatanga, which is Aotearoa's Centre of Research Excellence in Māori and indigenous knowledge. These relationships have been prioritised primarily because of their aligned interests in progressing work with Māori data and also the contribution that each can make towards accessing or collecting data that are relevant for both the IMSB and Tāmaki Makaurau Māori.

Finally, the Data Strategy Expert Panel consists of members who, collectively, bring a significant breadth and depth of knowledge and experience in data and research, Māori development and policy and planning. The panel's primary purpose is to provide the IMSB with advice on the data strategy's implementation. The independent advice of the expert panel - who are, again, experts in data and research concerning Māori development - also ensures a degree of 'safety' around tikanga Māori and technical robustness.

\section{Conclusion}

While the Māori Plan presents challenges and implications, these are being addressed and they are nothing more than 'growing pains' in a relatively new and pioneering process. The Māori Plan ultimately still provides a Māori vision for Tāmaki Makaurau, which has never been articulated at any previous point in the history of local government.

The development of the plan and work relating to its implementation, monitoring and evaluation are an approach the IMSB is facilitating to contribute to positive outcomes for Māori in Tāmaki Makaurau. The hope is that the sharing of the IMSB's knowledge and experience 
gained to date with other Māori and indigenous collectives will usefully contribute to ongoing positive conceptualisations of Māori and indigenous wellbeing. Further, collective and collaborative efforts around the collation and analysis of related data will create and grow 'space' within which such Māori and indigenous conceptualisations may flourish.

\section{References}

Baker K (2010). Whānau Taketake Māori: recession and Māori resilience - a report for the Families Commission, Families Commission, Wellington.

Belgrave M (2012). Negotiations and settlements. In Wheen N \& Hayward J (eds), Treaty of Waitangi settlements, Bridget Williams Books, Wellington.

Cunningham C (1996). He Taura Tieke: measuring effective health services for Māori, Ministry of Health, Wellington.

Durie M (2005). Nga Tai Matatu tides of Māori endurance, Oxford University Press, Auckland.

Durie M (2009). Pae Mana: Waitangi and the evolving state. In The Paerangi Lectures: Māori horizons 2020 and beyond, Massey University, Wellington.

Durie M, Fitzgerald E, Kingi TKR, McKinley S \& Stevenson B (2002). Māori specific outcomes and indicators: a report prepared for Te Puni Kokiri, the Ministry of Māori Development, Massey University, Palmerston North, NZ.

Independent Māori Statutory Board (IMSB) (no date). The Māori plan for Tāmaki Makaurau, IMSB, Auckland, aucklandcouncil.govt.nz/ EN/planspoliciesprojects/plansstrategies/unitaryplan/Documents/ Section32report/Appendices/Appendix\% 203.16.4.pdf.

Kingi TK (2005). Evaluation and measurement of cultural outcomes, Paper presented at the 2005 Aotearoa New Zealand Evaluation Conference, Taupo, NZ, 18-20 July 2005. 
Māori Economic Development Taskforce (2010). Iwi infrastructure and investment, Te Puni Kokiri, Wellington.

Royal Commission on Auckland Governance (2009). Volume one: report, Royal Commission on Auckland Governance, Auckland.

Statistics New Zealand (2013). 2013 census quickstats about Māori, Statistics New Zealand, Wellington, stats.govt.nz.

Walker R (2004). Ka whawhai tonui matou: struggle without end, Penguin Books, Auckland.

Wheen R \& Hayward J (eds) (2012). Treaty of Waitangi settlements, Bridget Williams Books, Wellington. 
This text is taken from Indigenous Data Sovereignty: Toward an agenda, edited by Tahu Kukutai and John Taylor, published 2016 by ANU Press, The Australian National University, Canberra, Australia. 